\title{
Hubungan persepsi, sikap dan jumlah anggota keluarga dengan jumlah konsumsi daging ular piton oleh pelanggan di pasar Beriman Kota Tomohon
}

\author{
P. Paat, F. N. S. Oroh, R. M. F. Osak, I. D. R. Lumenta. \\ Fakultas Peternakan Universitas Sam Ratulangi, 95115 \\ *Korespondensi (corresponding author): frankyoroh@unsrat.ac.id
}

\begin{abstract}
ABSTRAK
Penelitian ini dilaksanakan di Pasar Ekstrim (Pasar Beriman) Kota Tomohon. Tujuan penelitian ini dilakukan untuk mengetahui pengaruh persepsi, sikap dan jumlah anggota rumah tangga terhadap jumlah konsumsi daging ular piton di Kota Tomohon. Penelitian ini menggunakan metode survei dengan penentuan sampel secara purposive sampling. Model analisis data menggunakan analisis Pearson Correlation. Hasil penelitian menunjukkan bahwa hubungan variabel persepsi dengan variabel jumlah konsumsi daging piton memiliki hubungan negatif secara tidak signifikan. Hubungan variabel sikap dengan variabel jumlah konsumsi daging piton memiliki hubungan positif dan signifikan. Selanjutnya hubungan variabel jumlah anggota keluarga dengan variabel jumlah konsumsi daging piton memiliki hubungan negatif dan tidak signifikan. Hasil penelitian disimpulkan bahwa variabel persepsi memiliki hubungan negatif yang non significant dengan jumlah konsumsi daging piton, variabel sikap memiliki hubungan negatif yang tidak significant dengan jumlah konsumsi daging piton; dan hubungan variabel jumlah anggota keluarga memiliki hubungan negatif yang tidak signifikan dengan variabel jumlah konsumsi daging piton.
\end{abstract}

Kata kunci : Persepsi, Sikap, Anggota Keluarga, Konsumsi, Daging Piton

\begin{abstract}
THE RELATIONSHIP AMONG PERCEPTIONS, ATTITUDES, AND THE NUMBER OF FAMILY MEMBERS WITH THE CONSUMPTION OF PYTON SNAKE MEAT BY COSTUMERS IN "BERIMAN" MARKET OF TOMOHON CITY This research was conducted at the Extreme Market (Pasar Beriman), Tomohon City. The purpose of this study was to see the effect of perceptions, attitudes and the number of household members on the consumption of python meat in Tomohon City. This study used a survey method with purposive sampling sampling. Analysis of the data model using Pearson Correlation analysis. The results showed that the variable perception and consumption of python meat had a negative and not significant relationship. The relationship between attitude variables and the variable consumption of python meat has a negative and insignificant relationship. Furthermore, the relationship variable between the number of family members and the variable consumption of python meat has a negative and not significant relationship. The results of this study indicate that the perception variable has a negative and not significant relationship with the total consumption of python meat; Attitude variable has a negative and not significant relationship with the total consumption of python meat; and the relationship variable the number of family members has a negative and not significant relationship with the variable consumption of python meat.
\end{abstract}


Keywords: Perception, Attitudes, Family Members, Consumption, Python Meat

\section{PENDAHULUAN}

\section{Latar Belakang}

Indonesia memiliki keragaman satwa liar tidak endemik yang dapat dikembangkan untuk pemenuhan kebutuhan sandang, pangan, obat-obatan. Satwa liar yang dikonsumsi masyarakat tertentu baik satwa unggas, mamalia, ampibia maupunreptilia yang ditangkap dari kebun, hutan, sungai ataupun yang sudah dipelihara.

Satwa reptilia yang umum dikonsumsi seperti penyu, buaya, biawak dan ular. Ular sanca atau piton (Phyton) adalah salah satu jenis ular yang banyak dieksploitasi untuk kulit, makanan, dan obat-obatan tradisional yang sebagian besar obat Cina, di mana hampir setengah juta kulit ular sanca sendiri diekspor setiap tahun dari Asia Tenggara (Kasterine et al., 2012). Lebih lanjut dikatakan bahwa perdagangan komoditas ini memberikan pendapatan tunai bagi sebagian orangorang pedesaan di wilayah Asia Tenggara dengan mengumpulkan, membiakkan ataupun memelihara ular sanca. Satwa ular juga digunakan sebagai pangan yaitu beberapa jenis daging ular yang digunakan sebagai sumber lauk pengganti daging. Beberapa jenis daging ular sering diolah menjadi lauk, dengan jenis dan cara pengolahan yang berbeda tergantung dari lokasi daerah maupun negara domisili masyarakatnya.

Jenis makanan berbahan ular seperti daging ular goreng, sup, sate (seperti di Vietnam, Tiongkok, dan lainlain) ataupun garo rica (seperti di Sulawesi Utara, Indonesia). Orang Cina menyenangi makanan berbahan ular, dan mengunakan beberapa spesies ular yang dianggap memiliki nilai obat pada bagian tubuh tertentu ular seperti empedu ular disebutsebut untuk kejantanan pria, dan dianggap memperkuat dan mengembalikan vitalitas
Masalah utama atau tantangan saat ini adalah permintaan dan eksploitasi yang rasional dan berkelanjutan sumber daya termasuk satwa liar (Kyamakya et al., 2019) seperti ular piton. Permintaan akan kebutuhan daging dan kulit yang tinggi mengakibatkan perburuan dialam semakin tinggi yang mengancam populasi ular menurun. di dalam ekosistem, ular memiliki peranan penting seperti sebagai predator hama.di alam bebas ular memakan tikus sebagai hama tanaman, baik di sekitar hutan maupun sawah. Apabila populasi ular menurun di alam, maka hama tikus akan meningkat akibatnya petani akan merugi. Oleh sebab itu, pemanfaatan daging ular sebagai sumber protein alternatif seharusnya berasal dari budidaya ular dan bukan dari alam, agar keseimbangan ekosistem dapat terjaga.

Persepsi merupakan cara bagaimana konsumen memberi makna pada rangkaian rangsangan dan ini adalah proses kognisi, persepsi tidak saja penting dalam tahapan pemrosesan informasi namun juga berperan pada pasca konsumsi produk yaitu ketika konsumen melakukan evaluasi atas keputusan pembeliannya. Persepsi adalah suatu proses dimana individu mengorganisasikan dan menginterpretasikan kesan sensorik mereka untuk memberi arti pada lingkungan mereka (Subakti, 2018 dan Nandan et al., 2015). Perilaku konsumen menurut Marhaini (2011) adalah studi yang fokusnya adalah untuk mempelajari bagaimana perilaku konsumen dalam membuat keputusan untuk menggunakan sumber daya yang dimilikinya (waktu, uang, maupun tenaga) untuk mengkonsumsi barang yang dibutuhkan.

Di pasar Ekstrim Tomohon dikenal sebagai pasar yang dikunjungi pelanggan daging ular piton dari Kota Tomohon dan sekitarnya dan menjadi salah satu objek wisata turis mancanegara. Permintaan 
daging ular piton yang relatif tinggi di pasar Ekstrim Tomohon oleh karena berbagai maksud dan tujuan konsumen $m$ engkonsumsi makanan daging ular piton, baik untuk hobby/kesenangan, kenikmatan, ataupun untuk kesehatan. Biasanya mereka mengkonsumsi makanan daging ular piton ketika hari pesta seperti hari syukur lokal (pengucapan syukur), pesta ulang tahun, hari Natal dan Tahun Baru, dan hari-hari khusus lainnya.

Faktor yang mempengaruhi konsumsi seperti pendapatan keluarga dimana menurut Badoa et al (2016) bahwa pendapatan keluarga berpengaruh nyata terhadap konsumsi daging ayam, daging babi dan telur. Namun untuk konsumsi daging ular piton ditemukan di pasar "Beriman" Kota Tomohon konsumen yang membeli dan mengonsumsi daging tersebut terutama jika ada terjadi kelangkaan dan tingginya harga daging dan ikan di pasaran.

Berdasarkan latar belakang di atas, perlunya diketahui tentang beberapa faktor yang menyebabkan orang mengkonsumsi daging ular piton. Untuk itu perlu diketahui hubungan faktor-faktor persepsi, sikap dan jumlah anggota keluarga dengan jumlah konsumsi daging ular piton oleh pelanggan di Pasar Ekstrim Kota Tomohon.

\section{METODE PENELITIAN}

\section{Lokasi dan Waktu Penelitian}

Penelitian ini dilaksanakan di Pasar Ekstrim (Pasar beriman) Kota Tomohon pada bulan Febuari 2020 Sampai Maret 2020. Pemilihan lokasi ini dilakukan secara sengaja (purposive sampling) dengan pertimbangan bahwa pasar tersebut terdapat tempat penjualan daging ular piton.

\section{Jenis dan sumber data}

Sumber data yang digunakan dalam penelitian ini adalah data primer dan data sekunder. Menurut Sugiyono (2012), bahwa sumber primer adalah sumber data yang langsung dari objek yang diteliti, sedangkan data sekunder adalah data yang diperoleh dari instansi-instansi yang terkait dalam penelitian ini.

\section{Metode penentuan sampel dan responden}

Responden penelitian ini yaitu pelanggan yang membeli daging piton di pasar ekstrim Tomohon. Penentuan sampel responden mengunakan metode purposive sampling yang artinya teknik sampling non random (tidak secara acak) karena pengambilan sampel dengan cara menetapkan ciri-ciri khusus atau pertimbangan yang sesuai dengan tujuan penelitian (Singarimbun dan Effendi, 2012). Ciri-ciri khusus yang dipilih sebagai sampel responden yaitu pelanggan atau konsumen penggemar daging piton yang berbelanja di pasar Beriman Kota Tomohon.. Jumlah responden yang digunakan pada penelitian ini adalah 30 responden. Sampel tersebut diperoleh dengan menggunakan teknik sampel Accidental. Accidental Sampling adalah teknik penentuan sampel berdasarkan kebetulan, yaitu konsumen yang secara kebetulan/insidental bertemu dengan peneliti dapat digunakan sebagai sampel. Sugiyono (2012) memberikan acuan umum untuk menentukan ukuran sampel :

1. Ukuran sampel lebih dari 30 dan kurang dari 500 adalah tepat untuk kebanyakan penelitian

2. Jika sampel dipecah ke dalam subsampel (pria/wanita, junior/senior, dan sebagainya), ukuran sampel minimum 30 untuk tiap kategori adalah tepat

\section{Model analisis}

Data yang diperoleh dari hasil penelitian dianalisis dengan menggunakan metode deskriptif. Metode deskriptif dapat diartikan sebagai suatu metode yang berfungsi untuk mendeskripsikan atau memberi gambaran terhadap objek yang diteliti melalui data atau sampel yang telah terkumpul sebagaimana adanya tanpa 
melakukan analisis dan membuat kesimpulan yang berlaku untuk umum. Dengan kata lain penelitian deskriptif analitis mengambil masalah atau memusatkan perhatian kepada masalahmasalah sebagaimana adanya saat penelitian dilaksanakan, hasil penelitian yang kemudian diolah dan dianalisis untuk diambil kesimpulannya (Sugiyono, 2014).

Analisis yang digunakan untuk mengukur hubungan antara variablevariabel independen Persepsi, Sikap dan Jumlah Anggota Rumahtangga dengan variable dependen Jumlah Konsumsi Daging Piton menggunakan analisis korelasi Pearson menurut formula Siegel (2012), sebagai berikut :

$$
r=\frac{N \cdot \sum X Y-\left(\sum X\right) \cdot\left(\sum Y\right)}{\sqrt{\left\{N \cdot \sum X^{2}-\left(\sum X\right)^{2}\right\}} \cdot\left\{N \cdot \sum Y^{2}-\left(\sum Y\right)^{2}\right\}}
$$

Untuk pengujian signifikansi $\mathrm{r}$ (korelasi Pearson) digunakan uji-t dengan rumus :

$t=\frac{r \sqrt{N-1}}{\sqrt{1-r^{2}}}$

keterangan :

$\mathrm{r}=$ koofisien korelasi antara variable $\mathrm{X}$ dan Y

$\mathrm{N}$ = banyaknya observasi

$\mathrm{X}=$ variabel independen (Persepsi, Sikap dan Jumlah Anggota Rumahtangga)

$\mathrm{Y}=$ variabel dependen (Jumlah Konsumsi Daging Piton)

\section{HASIL DAN PEMBAHASAN}

\footnotetext{
Masyarakat Kota Tomohon sebagaimana masyarakat Minahasa umumnya selain mengkonsumsi daging ternak, juga menggemari daging hewan liar seperti daging babi hutan, kucing, kelelawar, tikus hutan, ular piton dan sebagainya. Daging-daging hewan liar tersebut dibeli masyarakat di pasar tradisional khususnya pasar ekstrim Kota Tomohon.
}

Kota Tomohon sebagai salah satu objek wisata, pasar tradisional Tomohon memiliki keunikan adanya pasar ekstrim yang membuatnya bertahan dan mendapat perhatian dari konsumen Kota Tomohon dan sekitarnya yang menjadi obyek wisata menarik bagi wisatawan dalam maupun luar negeri. Keunikan sebagai atraksi wisata yang tersedia di pasar tradisional Tomohon seperti adanya lapak untuk menjual daging hewan-hewan yang tidak biasa terutama bagi orang dari luar daerah Minahasa. Oleh sebab itu, kegiatan jual beli daging hewan-hewan di atas, sehingga pasar tradisional Tomohon juga terkenal dengan extreme culinary yang oleh pemerintah Kota Tomohon memberi nama Pasar Ekstrim Kota Tomohon.

Tabel 1 menunjukkan hasil analisis korelasi pearson variabel Persepsi, Sikap dan Jumlah Anggota Keluarga dengan Jumlah Konsumsi Daging Ular Piton di Pasar Ekstrim Kota Tomohon.

\section{Hubungan persepsi dengan jumlah konsumsi daging ular piton}

Persepsi merupakan sudut pandang atau pandangan seseorang terhadap suatu hal. Menurut Setiadi (2010), persepsi memiliki sifat subjektif, karena setiap orang akan memandang suatu objek atau situasi dengan cara yang berbeda-beda. Timbulnya persepsi berbeda-beda yang dibentuk oleh masyarakat dapat mempengaruhi sikap konsumen untuk mengambil keputusan dalam mengonsumsi daging ular piton yang merupakan daging ekstrim. 
Tabel 1. Hasil Analisis Korelasi Pearson

\begin{tabular}{|c|c|c|c|c|c|}
\hline & & Persepsi & Sikap & $\begin{array}{c}\text { Jumlah Anggota } \\
\text { Keluarga }\end{array}$ & $\begin{array}{l}\text { Jumlah Konsumsi } \\
\text { Daging Ular Piton }\end{array}$ \\
\hline \multirow{3}{*}{ Persepsi } & Pearson Correlation & 1 & $.511^{* *}$ & .158 & -0.175 \\
\hline & Sig. (2-tailed) & & .004 & .405 & .354 \\
\hline & $\mathrm{N}$ & 30 & 30 & 30 & 30 \\
\hline \multirow{3}{*}{ Sikap } & Pearson Correlation & $.511^{* *}$ & 1 & .299 & .016 \\
\hline & Sig. (2-tailed) & .004 & & .108 & .933 \\
\hline & $\mathrm{N}$ & 30 & 30 & 30 & 30 \\
\hline \multirow{3}{*}{$\begin{array}{l}\text { Jumlah Anggota } \\
\text { Keluarga }\end{array}$} & Pearson Correlation & .158 & .299 & 1 & -.357 \\
\hline & Sig. (2-tailed) & .405 & .108 & & .053 \\
\hline & $\mathrm{N}$ & 30 & 30 & 30 & 30 \\
\hline \multirow{3}{*}{$\begin{array}{l}\text { Jumlah } \\
\text { Konsumsi } \\
\text { Daging Ular } \\
\text { Piton }\end{array}$} & Pearson Correlation & -0.175 & .016 & .357 & 1 \\
\hline & Sig. (2-tailed) & .354 & .933 & .053 & \\
\hline & $\mathrm{N}$ & 30 & 30 & 30 & 30 \\
\hline
\end{tabular}

Keterangan: $* *)=$ Hubungan sangat signifikan

Hasil penelitian menunjukkan bahwa nilai Korelasi Pearson variabel Persepsi dengan variabel Jumlah Konsumsi Daging Piton sebesar -0,175 dengan tingkat signifikansi sebesar 0,354 ( $>0,05)$. Hubungan variabel persepsi dengan variabel jumlah konsumsi daging piton memiliki hubungan negatif dengan tingkat signifikansi yang non significant $(\mathrm{p}>0,05)$, berarti perubahan persepsi atau pandangan, kesan dan citra konsumen akan daging piton,secara tidak signifikan dapat menurunkan jumlah daging piton yang dikonsumsi.

\section{Hubungan sikap dengan jumlah konsumsi daging ular piton}

Sikap konsumen adalah suatu mental dan saraf yang berkaitan dengan perasaan untuk menanggapi, diorganisasi melalui pengalaman dan memiliki pengaruh yang mengarah dan atau dinamis terhadap perilaku. Sikap juga merupakan salah satu konsep yang paling penting yang digunakan pemasar untuk memahami konsumen. Hasil menunjukkan bahwa nilai Korelasi Pearson untuk hubungan variabel Sikap dengan Jumlah Konsumsi Daging Piton sebesar 0,016 dengan tingkat signifikansi sebesar $0,933 \quad(\mathrm{p}>0,05)$. Hubungan variabel Sikap dengan variabel jumlah konsumsi daging piton memiliki hubungan positif dengan tingkat signifikansi yang significant $(p>0,05)$, berarti perubahan sikap atau kecenderungan tindakan konsumen membeli daging piton, secara signifikan dapat menaikkan jumlah daging piton yang dikonsumsi. Sikap dengan jumlah konsumsi daging ular piton memiliki hubungan positif

\section{Hubungan jumlah anggota keluarga dengan jumlah konsumsi daging ular piton}

Permintaan merupakan keinginan akan produk tertentu yang didukung oleh kemampuan serta memuaskan keinginan dan kebutuhan hidup pembeli. Pada umumnya permintaan dipengaruhi oleh harga barang itu sendiri, harga barang substitusi, Jumlah anggota keluarga dan pendapatan keluarga, dan selera konsumen. Permintaan daging dapat diketahui dengan melihat banyaknya permintaan pada konsumen rumah tangga.

Hasil penelitian menunjukkan bahwa nilai pearson korelasi untuk hubungan variabel jumlah anggota keluarga dengan variabel jumlah konsumsi daging piton sebesar -0,36 dengan tingkat signifikansi sebesar 0,053 ( $>>0,05)$. Hubungan variabel jumlah anggota keluarga dengan variabel jumlah konsumsi daging piton memiliki hubungan negatif yang tidak signifikan $(p>0,05)$, berarti 
perubahan jumlah anggota keluarga konsumen, secara tidak signifikan dapat menurunkan jumlah daging piton yang dikonsumsi. Hasil penelitian ini sejalan dengan hasil penelitian (Kastalani, et al., 2017).

\section{KESIMPULAN}

Persepsi atau pandangan, kesan dan citra konsumen akan daging piton, secara tidak signifikan dapat menurunkan jumlah daging piton yang dikonsumsi pelanggan. Perubahan sikap atau kecenderungan tindakan konsumen membeli daging piton, secara tidak signifikan dapat menaikkan jumlah daging piton yang dikonsumsi pelanggan. Perubahan jumlah anggota keluarga konsumen, secara tidak signifikan dapat menurunkan jumlah daging piton yang dikonsumsi pelanggan.

\section{DAFTAR PUSTAKA}

Badoa, I.V., A.H.S. Salendu, F.H. Elly dan P.O.V. Waleleng, 2016. pengaruh pendapatan terhadap konsumsi daging dan telur di Kecamatan Siau Barat Kabupaten Kepulauan Siau Tagulandang Biaro. Jurnal Zootek 36(10):61-68.

Kasterine, A., Arbeid, R., O. Caillabet, and Natusch, D. 2012. The Trade in South-East Asian Python Skins. International Trade Center. Geneva.

Kastalani, Yemima dan H. Sularso, 2017. Analisis pendapatan, pendidikan dan jumlah anggota keluarga terhadap pola konsumsi daging ayam broiler di desa Sei Asam Kabupaten Kapuas. Jurnal Ilmu Hewani Tropika. 6(2): 48 - 51.

Kyamakya, C.K., C. N. Mololo, and S. G. Mbalitini, 2019. Bushmeat trade in Kisangani (DRC), constancy and abundance of mammalian species on the market from 1976 to 2016. International Journal of
Environment, Agriculture and Biotechnology 4(2):323-333.

Marhaini, 2011. Analisis perilaku konsumen dalam pembelian komputer merek acer. Jurnal Manajemen Bisnis 3(1):89-96.

Nandan, H.A. dan S. M. Hidayat, 2015. Pengaruh persepsi terhadap keputusan pembelian melalui motivasi konsumen. J. Investasi Fakultas Ekonomi Unwir, 1(1):1935.

Sugiyono. 2012. Metode Penelitian Kuantitatif Kualitatif dan R\&D. Bandung: Alfabeta.

Sugiyono, 2014 Metode Penelitian Kuantitatif, Kualitatif dan R\&D, Bandung : Alfabeta.

Siegel. 2012. A. Global Cancer Statistics CA a cancer J. Clin. 2015;65(2):87-108

Singarimbun, S. dan S. Effendi, 2012. Metode Penelitian Survei, Edisi Revisi, Pustaka LP3ES, Jakarta.

Subakti, H., D. Tenironama dan A. Yuniarso, 2018. Analisis persepsi konsumen. studi kasus molecular mixology di Loewy, Jakarta. Tourism and Hospitality Essentials (THE) Journal 8(1):31-37.

Sekaran, 2006, Research Methods For Business, Edisi 4, Buku 2, Jakarta: Salemba. Empat.

Silalahi, U. 2012. Metode Penelitian Sosial. Bandung: Refika Aditama 